\title{
ENGENDERING GLOBAL DEMOCRACY ${ }^{1}$
}

\section{Catherine Eschle, University of Strathclyde, Glasgow, UK}

\section{Introduction}

Liberal democratic ideas and institutions retain a globally hegemonic grip, having apparently triumphed over their historic competitors. Although the 'third wave' of democratisation has been on the retreat somewhat over the last decade, as have the more hubristic claims about it, many commentators can still perceive no other legitimate organising principle for states worldwide. Yet this hegemony is not uncontested. Long-standing leftist models of participatory politics may have been largely abandoned, but concerns about the limitations of liberal democracy remain high and a great deal of academic and activist energy has been devoted in recent years to the construction of innovative alternatives. Two sources of concern lie behind this paper. The first is the long-standing feminist claim that women have been consistently marginalised within democratic ideas and institutions. The second arises from more recent work on the iniquitous impact of globalisation. These concerns have both generated corresponding reconstructive strategies - but each body of literature ignores the problem raised by the other and thus remains significantly flawed. 
This paper is rooted in the belief that both gender hierarchies and globalisation need to be taken on board if democracy is to be made more meaningful for more people. Further, I argue that the most effective and radical tools for such a reconstructive project are not to be found in mainstream global schemes or in feminist proposals for a more women-friendly polity - or in some combination of the two. Attention is drawn instead to an alternative strand of feminist engagement with democracy, in the shape of debates about the democratisation of the feminist movement. I focus particularly on black and third world feminist interventions in these debates and their influence on efforts to construct more democratic movement organisation across national borders. These efforts point to the possibility of a more genuinely inclusive and participatory form of democracy, one that is not confined to states and that enables the most vulnerable women in the world to gain some control over the globalising processes that shape their lives.

\section{Globalisation, democracy and the marginalisation of women}

Globalisation can be defined as a process of intensifying global social interrelatedness, whereby space and time are compressed and previously separated locations brought into a new proximity. In popular understanding, globalisation is strongly linked to the diffusion of neoliberal economic orthodoxy through international financial institutions, the integration of markets and the rise of transnational corporations. It is a highly contested and controversial phenomenon, one clearly of great relevance to debates about the diffusion of democratic institutions throughout the world. ${ }^{2}$ Political science explanations of democratisation have not foregrounded globalisation as such but they do allow some role for related factors. These include the diffusion of modernisation processes outward from the West; the role of 
international elites; and the impact of long-term structural changes in state capacities, class relationships and transnational power balances (e.g. Potter et al. 1997; Huntington 1991; Luckham and White 1996). Some limited attention has also been paid to the ways in which pro-democracy activists may be in contact with those in other countries or influenced indirectly as part of the phenomenon characterised as 'snowballing' or 'contagion', whereby publicity about the struggle in one country encourages similar developments elsewhere (Huntington 1991: 100-105; Whitehead 1996: 250-252). Anthony Giddens has argued that the impact of transnational forces on social pressure for democratisation can be even less direct, in the form of 'the expansion of social reflexivity and detraditionalization' across the globe. He concludes that 'it is globalization, with its attendant transformations of everyday life, which surely underlies pressures towards democratization in the present day' (Giddens 1994: 110-111).

At the same time, globalisation is charged with undermining democracy. Two main problems are highlighted in the non-feminist globalisation literature. The first is a reworking in the context of economic globalisation of the familiar marxian argument that liberal democracy is undermined by the unequal capitalist relations associated with it. Thus Robert Cox points out that new democratic institutions have frequently been established at the behest of transnational elites that are unaccountable and that pursue neoliberal orthodoxy by insisting upon state withdrawal from economic planning, social provision and redistribution. New democracies can thus 'lack a secure base in a participant, articulated civil society', while newly elected governments are often so constrained that the effect has been to 'transform politics at the national level into management' (Cox 1997: 60-63). The second problem, highlighted particularly by David Held (1991, 1995), has to do with the territorial, national form of democratic institutions. Held stresses that the long-presumed coincidence between 
decision-makers, their constituencies and the impacts of their decisions has been disrupted by globalisation. Sources of power can now be a continent away from the communities affected by them and territorially-based democratic mechanisms fail to enable such communities to scrutinise, participate in or contest many of the processes shaping their lives.

There is a third way in which the diffusion of democracy has been limited, one which is generally ignored in non-feminist accounts. This is the fact that women have been marginalised as political actors within many new democratic regimes. The feminist literature on the transitions in central and eastern Europe documents a particularly dramatic fall in the number of women in national representative bodies across the region, from an average of one third of seats under 'state socialism', to an average of just under 10 per cent after the first liberal democratic elections ( e.g. Einhorn 1993; Watson 1993; Ward et al. 1992). Later in the 1990s, the numbers of women representatives rose slightly and then stabilised, reaching their highest levels in central European countries closest to EU membership. For example, in the 1995 elections in the Czech Republic, women made up 10 per cent of legislators, rising to 15 per cent in the lower house in 2000 . Women accounted for 13 per cent of representatives in Poland in both 1995 and 2000 (Jaquette and Wolchik 1998: 11; Jaquette 2001: 115). Latin American transitions from military dictatorships to liberal democracies saw women play a more prominent role as participants in movements for change, but their subsequent underrepresentation in consolidated national legislatures was even more marked. By 1995, women constituted only 5 per cent of representatives in Brazil and 9 per cent in Peru. Argentina stands out with 14 per cent in 1995 doubling to 30.7 per cent today, figures achieved as a result of quotas (Jaquette and Wolchik 1998: 11; Inter-Parliamentary Union 2002). Processes of transition from dictatorship on the African continent have been more uneven but, as elsewhere, women representatives remain a minority. They are a significant minority in 
Mozambique, South Africa, Namibia and Uganda, where again deliberate political measures have resulted in between 24 and 30 per cent of representatives being women (Pankhurst 2002: 125; Inter-Parliamentary Union 2002). There is significant variability within and across regions then, but also a stark continuity: the proportion of women in national legislatures in new democracies is never as much as a third of the total and it is frequently much lower. In many cases, this means that women are more marginalised as political actors than they were before or during the transition process.

Feminist explanations of this phenomenon have tended to stress the specific social and political situation in each country and/or of each region. This has been particularly evident in analyses of the central and eastern European context, which have stressed the common heritage of 'state socialism' and its approach to 'the women question'. This approach involved the incorporation of women in large numbers into the workforce and political institutions, the latter via communist party quotas, but little effort was made to change cultural attitudes or to challenge the domestic division of labour. Ultimately, economic and political mechanisms to sustain the public role of women collapsed with the regimes that introduced them, and that role in itself was discredited. The region has also seen the revival of localised conservative, religious and nationalist forces which emphasise women's reproductive capacity and homemaking role and which construct politics as a masculine domain (Einhorn 1993; Posadskaya 1994; Watson 1993). In contrast, commentators on the Latin American transitions point to the relatively high public profile of women in a range of popular movements opposing military rule, their influence helping to ensure the creation of women's ministries and several constitutional safeguards. The low proportion of women's representatives in this context is due rather to the difficulties faced by autonomous social movements in relating to institutionalised state power after transition. Women's movements (and feminist 
commentators)continue to be significantly divided on the strategic implications of their relation to the state (Jaquette and Wolchik 1998: 5-6; Jaquette 2001: 113-114; Alvarez 1999). The destabilising impact of populism in the region and the differential institutionalisation of party systems may also be relevant to women's marginalisation (Waylen 2000). With regards to Africa, Donna Pankhurst's (2002) survey of analyses of gendered democratisation processes points to a central emphasis on the legacy of colonial rule (including economic under-development, the abuse of state power and ethnic rivalry) and on the non-ideological, identity-driven conflicts of the post-Cold War context, all of which severely constrains women's political participation. Shirin Rai sums up some of the crucial differences:

...it matters whether a political transition occurs in the context of internal pressures and political movements or is the result of external, international, pressure; it matters whether agenda-setting takes place within the context of a transition that is relatively peaceful and managed, or in the context of a crisis; it matters whether the space of civil society organisations to mobilise public opinion is constrained or relatively open; it matters whether the dominant political discourse is largely secular or not. (Rai 2000: 11)

However justifiable this emphasis on context-specific factors, it cannot account for the common experiences of marginalisation faced by women in new democratic institutions in different contexts. Nor does it face up to the fact that the proportion of women in national institutions in these democracies is now closer to the norm for so-called 'mature' or 'advanced' democracies. It is important to note here the achievement of the northern European, Scandinavian countries, which have consistently elected between 35 and 45 per cent women. However, most 'mature' democracies do not approach these levels. The UK 
currently has 17.9 per cent women in its lower house and the US only 14 per cent. These scorings place them behind several of the newer democracies, and this is despite significant rises over the last decade in levels of women's representation in both countries (Jaquette 1997: 26-27). Such advances remain fragile. The highest levels of female representation tend to be achieved through political measures, which are open to legal contestation and policy change (Squires and Wickham-Jones 2001). There is little evidence that the gap between Scandinavian countries and other 'mature' democracies is likely to be bridged over time, in some inevitable process of modernisation that will ultimately bring newer democracies up to the same level (Hawkesworth 2000: 226-227). Women still remain substantially underrepresented as political actors in most democracies and there are clearly macro-level forces that need to be taken on board when explaining this fact.

The first possibility to consider is that gendered hierarchies have been built into the globalisation processes through which democracy has been diffused round the world. The intersections between gender and globalisation have received significant feminist attention in recent years, particularly in terms of the impact of neoliberal economic processes upon women (e.g. Marchand and Runyan 2000; Afshar and Barrientos 1999; Basu et al. 2001). Two aspects of these processes have been emphasised: first, the restructuring of production and consumption by transnational corporations, incorporating women into the global division of labour in new ways; and, second, the disproportionate impact upon women of IMF- and World Bank-driven structural adjustment programmes. Such programmes are associated with the privatisation of state-owned utilities and services that has led to large-scale female unemployment, particularly in central and east Europe, and with large-scale cuts in social spending and welfare programmes that have increased women's unpaid domestic and caring labour. ${ }^{3}$ Of course, feminist accounts of democratic transitions have long acknowledged that 
accompanying economic restructuring has played a crucial role in limiting women's political participation ( e.g. Einhorn 1993: 127-142; Watson 1993: 78-82). However, it is now increasingly recognised that these processes of restructuring have a transnational dimension and that their effects on democracy within a region need to be analysed as part of the wider globalisation phenomenon. ${ }^{4}$ Further, attention has been drawn to the fact that the national and international elites co-operating in processes of neoliberal restructuring (and global governance more generally) have been largely male, with their decision-making procedures and neoliberal values thus incorporating masculinist biases and with limited access for women's representatives (O’Brien et al. 2000; Meyer and Prügl 1999). All this enriches Cox's marxian claim that the dissemination of formal democracy is undermined by the structural inequalities of globalised capitalism that sustain an unaccountable transnational elite. Feminist work indicates that such inequalities operate through gender as well as national and class divisions.

In addition, globalisation processes behind the spread of democracy may be gendered in terms of their cultural implications and effects. For example, feminist literature on central and east Europe highlights the intersection of globalised neoliberalism with local nationalisms, which together have constituted democratic politics as a 'man's business' to which women are not suited, with legislation and constitutional clauses explicitly oriented toward 'enabling' women to stay at home and fulfil role s as mothers of the nation and as unpaid support workers (e.g. Watson 1993: 74-77). Clearly, the revived significance attributed to unitary national culture and autonomous territorial control in the face of the globalising disjunctures, as indicated by Held, relies heavily upon the restructuring of gender and economic relations. Further, reactionary nationalism can be seen as one of a range of transnational fundamentalist responses, intimately interconnected with the broad processes 
of detraditionalisation and social reflexivity outlined by Giddens. Feminist accounts indicate that women's bodies and sexuality have been a particular site of struggle over detraditionalisation in central and eastern Europe and in Asia, with nationalist and religious forces vying with globalised media and sex industries for ideological control ( e.g. Klimenkova 1994; Hanochi 2001). The global expansion of reflexivity and detraditionalisation, then, is a highly uneven and unevenly gendered process. Resistance to it may constrain rather than enhance women's participation in new democracies.

The second possibility to consider is that there are gendered hierarchies built into democracy itself. Although feminist analyses of central and east Europe have focused on the legacy of a flawed and cynical 'state socialist' attempt to build a more substantive and participatory politics, there is also an extensive feminist literature on the limitations of liberal models of politics. Four shared themes can be identified in feminist criticisms of both liberal and leftist versions of democracy.

First, much feminist argument implies that established approaches to democracy are flawed because they privilege state and/or economic power. Feminists have long claimed that gender is also an important site and source of power, functioning to privilege masculine traits, roles and values over feminine equivalents in most realms of social life (e.g. Beechey 1979; Walby 1990). The second, related, problem is that established constructions of democracy remain limited in scope. The widespread acceptance of a distinction between public, political life and private, domestic, life - and the continued association of women with the latter - has been particularly criticised (e.g. Elshtain 1981; Pateman 1989: 118-140). Third, feminists have argued that the models of agency underlying democratic frameworks privilege masculine roles or traits. They insist that women rarely have the opportunity or the desire to 
live as separate, competitive and rational persons to the degree presumed by liberal ontology or to define themselves predominantly in terms of class identity, as presumed by marxists (e.g. Benhabib and Cornell 1987: 10-13; Held, V. 1993: 171-173, 182-185). Finally, some feminists have been critical of the approaches to change implicit in liberal and leftist versions of democracy. The strategies of incremental institutional reform and convulsive revolution in economic relationships, and the state-centrism that many reformists and revolutionaries share, are attacked as inadequate to tackle the gendered hierarchies seen as pervasive in society and the state (e.g. Levine 1984; Brown 1995).

If they are to result in a more inclusive politics, efforts to reconstruct democracy in an era of globalisation need to take on board the gendered marginalisations built into the very heart of dominant versions of democracy. Conversely, efforts to overcome gendered marginalisations need to grapple with the ways in which these are tied into processes of globalisation. Yet these intertwined problems with democracy have, until recently, been treated as if they were entirely distinct. The next section looks at reconstructive strategies that can be divided into (non-feminist) global schemes and (non-global) feminist alternatives.

\section{Reconstructing democracy: global and feminist frameworks}

Academic efforts to reconstruct democracy in response to the problems caused by globalisation have emerged from international relations, sociology and political theory. To a large extent, they overlap with the literature on 'global governance', concerned as they are with the need to make international governing institutions and regimes more effective, participatory and accountable in the face of the kind of the neoliberal-induced inequalities 
and the disjunctures between democratic institutions and power described above. The most high-profile work of this kind draws on the liberal cosmopolitan tradition and include the work of David Held $(1995,1998)$ and the Commission on Global Governance (1995). Both begin by arguing for the reform and expansion of liberal rights and duties to make them more universally acceptable and internationally applicable. They then put forward proposals for institutional reform aimed at entrenching those rights and duties. These proposals range from broadening representation on the Security Council to establishing regional and global legislative assemblies. An enhanced consultative and policy-implementation role for civil society actors such as international non-governmental organisations (INGOs) also features strongly. A final tranche of reform proposals centres on the global economy and includes the establishment of a minimum wage, debt alleviation and the creation of a new global coordinating body, with Held arguing in the long-term for the creation of a more diverse, multisectoral and pluralised economic system.

Although some of these proposals have far-reaching implications, the point remains to modify the worst aspects of the market economy, not to abandon market principles entirely. Globally-inclined marxists demand more radical measures. Neogramscians like Cox (1996, 1997) call for diverse movements inside a state to join together with a class-based unifying party in order to gain control of existing state bodies and thus to construct a more substantive, participatory democracy and socialised economy. Following the consolidation of national struggles, these movements could combine to create more radically democratic inter-state organisations, although such a development is made ever more difficult by the fragmentary effects of the globalised economy. ${ }^{5}$ In contrast, world-systems theorists await the collapse of national and international institutions with a confidence bolstered by their underlying structuralist interpretation of marxism and their accompanying belief that the 
activities of 'anti-systemic' social movements will exacerbate underlying structural tensions (Amin et al. 1990; Arrighi et al. 1989). World-systems theorists have as yet paid little or no attention to radical democratic alternatives to the current system. Arguably, their anti-statist leanings point towards a participatory marxist vision of a post-capitalist world in which states have 'withered away' and been replaced by a pyramidal structure of self-governing collectives.

Postmarxists accept the veracity of aspects of Marx's critique of capitalism and his commitment to collective action and economic change. However, they reject the marxist reduction of oppression to economic exploitation, social struggle to class struggle, and radical change to the transformation of the mode of production. Influenced by new social movement (NSM) theory and the writings of east and central European dissidents, postmarxists frequently argue for the revitalisation of civil society as the core of a new radical democratisation project (e.g. Cohen and Arato 1992). A global version of this argument has emerged, most notably in the work of Richard Falk and Ronnie Lipschutz. ${ }^{6}$ Global civil society is here depicted as a realm of social interaction between the global economy and state-system and as a potential site of challenge to both. It is constituted by diverse, transnational NSMs, which are seen as a force for democracy because they enable the marginalised to speak and because they seek to constrain and transform the power of the state system and global economy.

Proposals to overcome the gendered marginalisations of democracy are largely to be found in feminist democratic theory, a body of work attempting to reconstruct democratic theory and institutions in order to create a more 'woman-friendly polity' (Jones 1990). Perhaps the longest-standing strategy here is liberal and reformist in orientation, demanding incremental 
institutional changes to expand women's public presence. This can involve advocacy of a range of social policies, such as the provision of child-care facilities, aimed at giving women the time and skills to participate as equals in the public realm. Anne Phillips (1995) has focused instead on reforms of the political system, arguing for quotas of women representatives on party lists and in parliament.

Other feminist democratic theorists have rejected the aspiration for equality within existing institutions and called for the transformation of these institutions on the basis of the specificities of women's modes of being and acting. One such 'difference feminist' strategy is Iris Marion Young's 'democratic cultural pluralism'. Young sees women as one of a range of oppressed social groups. She argues that the participation of such groups in democracy requires the cultivation of culturally diverse forms of political communication, the adoption of 'group conscious' policies, and the institutionalisation of mechanisms enabling groups to generate and veto policy (Young 1990, 1996). An alternative 'difference' strategy is widely referred to as 'maternalism' because it calls for the protection and diffusion of the nurturing, relational values and modes of being traditionally associated with women and their mothering role. These are envisaged as the basis of a new mode of ethical political discourse and active citizenship (Elshtain 1981, 1990; Ruddick 1990).

These two difference approaches have provoked substantial controversy within feminism for their focus on, and assumptions about, women. Several of their critics share the desire to transform liberal institutions but seek to do so by facilitating the participation and reconciliation of both women and men. The recent revival of 'republican' political thought has been influential here, with its emphasis on participatory, active citizenship, and processes of collective deliberation in the 'public sphere'. Feminist sympathisers put forward 
reformulations of citizenship that can encompass women as well as men. They argue that rational and impartial processes of deliberation need not be gender-specific and that such processes should be encouraged to proliferate in varied, dispersed public spaces (Dietz 1992; Mouffe 1993; Benhabib 1996).

The above are diverse and undoubtedly path-breaking schemes. Yet one problem is immediately apparent: global and feminist arguments have been constructed largely in ignorance of the other. Global schemes are thus in danger of replicating gendered marginalisations on a grander scale and feminist efforts to overcome those marginalisations have, until recently, been limited to national institutional forms that may be increasingly anachronistic. There are historical and political factors at work here that have been well rehearsed in feminist and IR literature: entrenched male dominance and masculinist bias in the academy, on the one hand; and, on the other, the entrenched divide separating the study of life within states from the study of life between them. Thus these global and feminist approaches have largely talked past each other. Yet notwithstanding this mutual neglect, I want to argue that these approaches share several problematic assumptions about the substantive underpinnings of democracy. Further, these assumptions feed into and reinforce the neglect of gender and globalisation outlined above. At the risk of unfairness to the nuances of individual approaches, I will sketch out these common limitations under the broad-brush headings of power, politics, agency and change.

Most of the global and feminist schemes examined above adopt an exclusive focus on one or two sources of power: gender, the state-system and/or the global economy. This can be described as a 'monist' or 'parallelist' approach to sources of power (King 1988: 45, 51). Other sources are ignored and excluded from democratic scrutiny. Thus non-feminist global 
schemes fail to recognise the possibility that the state system and the global economy may be intertwined with gendered hierarchies. Non-global feminist democratic theorists are concerned primarily with the interconnection between state power and gender and consequently tend to neglect the power relations that women face in the home, in the economy and in the cultural domain.

There are some exceptions on this point. For example, Iris Young has drawn attention to processes of cultural domination and to more direct forms of violence affecting ethnic and sexual minority groups as well as women more generally (1990: 53-63). In more recent work, and in acknowledgement of arguments about globalisation, Young also discusses ways in which relationships of power and interdependence might stretch across states, thus requiring the extension of democracy beyond borders. Interestingly, her discussion becomes focused on relations of self-determination and justice among groups of people and on necessary changes to the regulatory organisations of the interstate and economic systems, appearing to leave concerns of gender inequality behind (Young 2000: 246-275). Amongst the nonfeminist global theorists, David Held's liberal cosmopolitan model explicitly identifies multiple sites of power, from the body to the state (1995: 176-185). There is space here for the recognition of gendered hierarchies and of the need to tackle them. However, Held's global institutional proposals, like Young's, leave gender out of the picture. He reverts to a parallelist focus on inter-state organisations and multinational business.

Closely related to the problematic theorisation of power is the shared insistence that democratic politics should remain limited in scope, confined to specific social locations. Non-global feminist democratic theorists are concerned to reinscribe politics within the public sphere or polity, for reasons that will become clearer below. The fact that the 
boundaries of the polity usually map on to the boundaries of the national community and the state either does not register with these theorists or is not seen as a problem, Young's recent work being a rare exception. Even in feminist republican models that suggest politics could be manifested in a range of diverse public realms and practices, relationships beyond and between states are not discussed. Young's narrower focus on institutional reforms of the UN is indebted to the work of cosmopolitan liberals like Held. Notwithstanding their concern with NGOs, liberals tend ultimately to focus their institutional proposals on opening access to state and inter-state institutions, thus confirming the state as the container and mediator of democracy as well as the major actor in global politics. Neogramscian work may remain opaque on the ultimate role and fate of the state (Colas 2002: 15) but much of it seems to me to point to the defence of a resocialised and accountable state as a potential bulwark against neoliberal forces and, importantly, as the necessary conduit of a politics of resistance. Politics is confined in other ways by world-system theory, which prioritises the struggle against capitalism, and by the global civil society framework, which constructs a fictitious space between and beyond the state and economy that functions to obscures the extent of relations of power (see Eschle 2001b; Colas 2002). In all approaches, democratic politics remains boxed in and certain social realms and practices escape its purview.

One result is that no global approach interrogates the boundary between the political and the domestic sphere, and the ways in which this boundary may structure access to global processes and their impact. Perhaps more surprisingly, feminist democratic theorists have also maintained a clear distinction between public politics and domestic life. Their focus on the public can be understood as a response to the theoretical and practical difficulties of an overly expansive second-wave feminist vision in which all of private life was to be subjected to political scrutiny. Yet a retreat to the conventionally demarcated public is problematic 
because it ensures that the 'private' intimate and economic relationships to which earlier second-wave feminists legitimately drew attention are now almost entirely exempt from collective democratic scrutiny.

Another key problem is that of agency. Global liberal and marxist approaches rely on notions of the political actor already extensively criticised as individualist and masculinist by feminists. In contrast, feminist democratic theorists are centrally concerned to recover women's contribution to politics. Difference feminists have been criticised for a view of women's agency that assumes women share certain traits and roles or experiences of oppression centering on motherhood and the family. There is a danger here of restricting agency to particular types of women and the role of men remains unclear. In an effort to avoid this problem, feminist republicans and reformists strive to factor women into existing models of agency. Republicans insist that active citizenship can be made more womenfriendly but do not specify concrete strategies to achieve this. Reformist suggestions include quotas of women in parliament or social policies to encourage the political participation of women more generally, but it could be argued that these are ways of modifying the masculinist biases of liberal individualism while still accepting this model overall. Further, most feminist democratic theorists tend to assume that political agency is shaped within and directed toward individual nation-states. Young's work is again worth noting for the argument that individuals have multiple group identifications, which include but are not reducible to nationality, and her recent assertion that group identities such as nationalism should be reconceptualised in interdependent and relational terms rather than in terms of independence and autonomy (e.g. 2000: 251-265). In contrast, non-feminist global theorists frequently assume an all-too easy cosmopolitan identification that functions to downplay the 
complex ways in which individuals are embedded in multidimensional relations with others and in diverse communal identifications.

Finally, there are significant drawbacks in the models of change implied by these democratic schemes. Global and feminist reformists rely on a top-down, elite-led, state-centric approach while their revolutionary opponents argue for an all-or-nothing process of class-based counter-hegemony or structural collapse. Such polarised views about the possibilities for change can be criticised for complacency or totalising pessimism, both of which can lead to political inaction. An alternative is offered by some strands of feminist work and by global civil society theorists. The latter imply a more nuanced view of ongoing transformation through social self-organisation, as exemplified by a range of contemporary movement activism. However, one difficulty here is the reliance on idealised and exclusionary ideas of what movements are like. For example, global civil society theorists join world-system theorists in assuming that contemporary movements are 'new', intrinsically progressive, anticapitalist and anti-statist. This is despite the fact that NSM theory has already been extensively criticised within sociology for universalising certain specific characteristics to all contemporary movements, thus obscuring historical continuity, geographic diversity and more reactionary and fundamentalist elements.

Contemporary women's movements tend to be ignored by global theorists but feature strongly in some feminist democratic theories. Maternalists emphasise that women's mobilisations like that of the Argentinean Mothers of the Plaza de Mayo are key forces for democratic change. The problem here is that such mobilisations may rely upon conservative, essentialist assumptions about appropriate women's roles. Conversely, feminist republicans allow a role for a range of movements, including women's - as long as they are non- 
essentialist. Yet this strategy is also problematic as many women's mobilisations would thus be excluded, not all of which can be assumed to be non-progressive. Thus many feminist theorists too have a narrow and exclusionary view of the kind of movement activity that could usher in a more democratic order. What is more, none except Young pays attention to the possibility of, or need for, movement activism that can cross state borders. Young has emphasised that diverse movements can be the bearers of democratic ideas and practices and her later work draws attention to 'global social movements that have affected the policies of international institutions' (2000: 272). However, she ends up evaluating movement contributions almost exclusively in terms of their impact upon state and inter-state institutions. It is surely worth considering whether movements may play a more complex role in processes of change, particularly in conditions of globalisation (see Eschle and Stammers 2001).

In sum, then, both non-feminist global approaches and feminist democratic theory are built upon reductive or otherwise problematic assumptions about power, politics, agency and change. Taking different forms in different approaches, these problems feed into the more general tendency of global theory to ignore feminist concerns and that of feminist democratic theory to pay little attention to the impact of globalisation. However, on this last point, Young's recent consideration of aspects of globalisation is perhaps indicative of things to come. It can be seen as part of the more general trend in feminist academic enquiry in recent years to make globalisation of central analytical concern, as highlighted above. This trend has also encouraged feminist interventions in global governance debates, focusing on the gendered character and exclusions of international organisations and on the responses of women's movements, and particularly NGOs (e.g. Meyer and Prügl 1999; O’Brien et al. 2000). Such interventions tend not to be couched in the language of democracy but rather in 
terms of arguments for inclusion, empowerment, civil society, agenda-setting and transformation. However, there is an obvious resonance with discourses about extending democracy, particularly with the liberal cosmopolitan framework and its emphasis on NGOs as vehicles for enhancing representation of marginalised groups in international organisations (see Dickenson 1997). It could be argued that these feminist interventions add a more radical edge to Held's liberal cosmopolitan ideas, because they tend to bring with them a stress on the multiple exclusionary effects of neoliberal restructuring. This leads to an awareness of the ways in which movements and NGOs are compromised by their positioning in the global economy and to demands for fundamental restructuring of global economic institutions and practices as part of the global governance project ( e.g. Runyan 1999; Stienstra 1999). However, it seems to me that the central preoccupation of feminist global governance literature is still with factoring participation through states and inter-state institutions: the feminist democratic imagination has thus been extended beyond the bounded nation-state but not beyond the confines of the state-system.

The same could be said of the efforts of sociologists Nira Yuval-Davis (1997a, 1997b) and Ruth Lister (1997) to reconstruct citizenship in ways that take on board the exclusions generated by gender, ethnicity and national borders. In ways that resonate with feminist republicanism, both theorists insist that citizenship needs to recognise and affirm difference, necessitating enhanced dialogue between sections of society and state action in favour of more marginalised groups. Further, they argue that citizenship should be reconfigured as a 'multilevel' concept denoting the relationship of an individual to sources of governance above and below the state. However, for Yuval-Davis, the state 'continues to be the primary political target', source of social power and guarantor of citizenship rights (1997a: 20-21). Lister extends citizenship rights to the international domain but is primarily concerned with 
the implications for international law and the actions of states (1997: 56-63). While these are undoubtedly important areas for change, it seems to me that there are more fundamental questions about the form, location and extent of globalised democracy that remain to be considered. This leads me to suggest a turn away from feminist reconstructions of the polity, global governance and citizenship, toward efforts to democratise feminist movement politics.

\section{Feminist movement democracy}

The construction of a democratic feminist movement was a high priority in early secondwave, western feminist organising. This was due partly to the influence of participatory marxist and anarchist precepts, and partly to the paradoxical experience of marginalisation within the movements that tried to put these precepts into practice. It also flowed from analyses of the pervasive nature of gendered power, at that time theorised in terms of 'patriarchy', which encouraged the expansion of the political into the personal. All this led to a conceptualisation of democracy as the contestation of hierarchical, coercive relations wherever they occur in social life - including in the private, domestic realm - and the construction of inclusive, participatory alternatives. Democracy within the feminist movement took the form of small, non-hierarchical groups, with activities divided equally between participants and decisions taken through inclusive dialogue that was expected ultimately to generate consensus. The movement was also perceived to be a source of democratisation in society more generally. It could enable women's agency in the context of pervasive patriarchal power and it could contest power relations in previously naturalised areas of social life, particularly intimate and family relationships (e.g. Passerini 1994; Rowbotham 1986; Phillips 1991: 121-124). 
This model of democracy within and through the feminist movement was the subject of criticism from its inception. It has been argued that 'structureless' participation masks informal elites; that it hampers an effective division of labour; and that it is unsustainable, self-indulgent and a misplaced priority (Freeman 1984). It is partly criticisms such as these that have encouraged feminist democratic theorists to turn to questions of inclusion within the national polity. However, although some criticisms of feminist movement democracy do have purchase, they do not necessarily invalidate the entire project. Rather, they point to inconsistencies in formulation and inadequacies in implementation. Indeed, it seems to me that the major weakness in second-wave feminist movement democracy was not too much participation but too little; not that democracy was too expansive but that it was not expanded far enough. It is my contention that such an analysis receives support from black and third world feminist interventions in debates about feminist organising.

The label 'black and third world feminist' is controversial but widely invoked. ${ }^{7}$ I am using it here to refer to writers and activists who have sought, amongst other things, to unmask the operations of racism in the white-dominated, west-centric second-wave feminist movement. Black and third world feminists have criticised theories of patriarchy for failing to reflect their experiences of multiple oppressions and especially of racism. They argue that white women's complicity in racist power is thus obscured and that the allegiance of black women to black men in anti-racist struggle is jeopardised. Accounts of the public/private divide have been accused of universalising a white middle-class model of the family and of presuming that the family is the source of all women's vulnerability. Another focus of criticism has been the tendency of white feminist narratives that eradicate the agency of black and third world women, presenting them as victims and ignoring their struggles within and beyond feminism. 
Finally, diverse feminist strategies for change have been attacked. From institutional reformism to radical feminist struggles around sexuality, these are seen to have little relationship to the priorities of many black and third world women. ${ }^{8}$ Such arguments imply that early second-wave feminist movement democracy was not expanded to confront racialised relations of power in society and in the movement. Participation was limited largely to a white middle-class elite that universalised from its own experiences to speak for others.

These limitations of white, western feminist theory and practice have also scarred efforts to organise across national borders. One high-profile approach to such organising draws on the notion of a 'global sisterhood' and assumes that a potentially global solidarity amongst women can be built upon the common experience of the patriarchal control of female bodies (Morgan 1985). Black and third world feminists have rejected the idea that women worldwide share such a common experience, that experience can automatically give rise to a shared politics, or that such a politics requires transcendence of history and geography (e.g. Mohanty 1998: 258-264). This critique has frequently encountered a defensive response whereby organisation and analyses have been confined to individual countries, to the local level, or to more specific shared identities. Yet such strategies simply reduce the scope and inclusivity of struggle rather than offering solution to the problem of how to organise for change effectively, sustainably and democratically. Indeed, conflict and fragmentation within many autonomous black and third world women's groups has encouraged the elaboration of arguments for more inclusive and democratic modes of organisation. These arguments tie in with a distinctive new strand in transnational feminist organising, one that moves away from the global sisterhood position. I will discuss these developments here under the now-familiar categories of power, politics, agency and change. 
Black and third world feminist writings tend to share a commitment to the view that power is pervasive throughout society. Many also recognise that power can be global in its reach. However, they argue against approaches that privilege one form of power globally, such as radical feminist theories of patriarchy or marxist analyses of capitalism. Rather power is seen to have many sources and to take many forms. Further, many black and third world feminists argue that these multiple forms of power intersect, manifesting themselves simultaneously in context-specific ways to produce particular conjunctures of oppression (King 1988;

Crenshaw 1998; Collins 2000). A shift to this kind of view was evident in the conference negotiations held during the UN Decade for Women. Many white western feminists initially insisted that the conferences should be discussing 'women's issues' such as sexual autonomy and equal pay, rather than 'political issues' such as the Israeli-Palestinian conflict and processes of economic development. This stance gave way in many cases - though not all under the weight of the insistence of black and third world feminists of the need to recognise different priorities in different contexts and to broaden the scope of feminist struggle (Bunch 1987: 283-305; Tinker and Jaquette 1987: 422). Arguably, the intersectional approach is now widely accepted as the basis of feminist organising and analysis in the context of globalisation (see e.g. Marchand and Runyan 2000; Basu et al. 2001; Peterson 2002 ).

In terms of the location and scope of politics, many black and third world feminists have restated the second-wave view that politics must be expanded into social life and not limited to certain spheres. However, whereas early second-wave formulations frequently supposed that a certain mode of political action was appropriate in all contexts, the insistence in black and third world feminist critiques that power is intersectional as well as pervasive encourages the important modification that politics must be located as well as expanded. According to 
Patricia Hill Collins, black women's experiences and social roles 'foster a distinctive form of political activism based on negotiation and a higher degree of attention to context' (2000: 221-222). Collins' analysis implies that strategies to contest power need to be developed in specific historical, geographical and social locations and not determined by some prior, universalising theory.

This should not be taken to imply that there can be no boundary between the political and private, intimate life. Rather, it involves a recognition that such boundaries and efforts to maintain or move them are themselves political and need to be openly negotiated by those affected. Nor should it be thought that those from outside a particular location or unaffected by a particular issue can have nothing of value to offer to efforts to get organised. On the contrary: the insistence on context-specificity in black and third world feminist argument is frequently combined with an argument for a politics of connection. This stems partly from a recognition of the tactical necessity to engage in 'alliances' and 'coalitions' (Reagon 1983; Sandoval 1995; Parmar 1989), and partly from an epistemological belief in the partiality of all standpoints and the consequent need to engage in dialogue with others to generate a fuller picture of reality (Collins 2000: 251-271). The resonance with current efforts in transnational feminist organising is obvious. Take, for example, the model of 'transversal politics' developed by the Italian Women in Black. In their work with feminist Serb and Croats and with Palestinians and Israeli Jews, this group has devised a process of coalition-building through dialogue in which participants recognise the historically specific nature of their own identities, acknowledge the partiality of their perspectives and attempt to be open to exchanges with others. ${ }^{9}$ 
A transversal politics of location and connection demands explicit attention to concrete mechanisms that enable open dialogue, such as limiting speaking times, allowing each to speak in turn, and facilitating intensive one-to-one conversations. On a transnational level, it also requires efforts to take on board linguistic diversity. Possible measures here include communicating in more than one language, non-verbally and through translators.

Furthermore, open dialogue also requires efforts to tackle the power relations between participants that structure access to dialogue and shape its outcomes. Applied to transnational politics, this necessitates that political actors make proactive efforts to redress the iniquitous geopolitical distribution of economic, social and technological resources. Thus the locations of meetings and organisations should be made accessible to third world women and funds targeted to enable the poorest to participate in agenda-setting via the institutionalisation of systematic consultation mechanisms and regular face-to face exchanges. Such practices can be seen in feminist mobilisation against the North American Free Trade Association (NAFTA) and associated economic processes. Trinational meetings were held in Mexico. The group Mujer a Mujer published several newsletters in Spanish and English. Canadian groups sponsored the participation of Mexican women activists in a joint tour to oppose free trade. The white-dominated Canadian National Action Committee on the Status of Women recruited more women of colour to its membership and executive and invited guests from around the world to its general meetings. Analysts have concluded that these measures point in the direction of a more egalitarian and sustainable way of constructing transnational feminist alliances (Gabriel and Macdonald 1994: 549-554, 558-562; Waterman 1998: 160171).

This transversal politics of location and connection requires and enables a particular kind of political agency. Neither the national citizen nor the transcendent global cosmopolitan is an 
adequate formulation. Instead, it is crucial to begin by 'situating the self' in national locations, taking on board the ways in which this location is stratified by ethnicity, class, sexuality and processes of migration and displacement (e.g. Mohanty 1998: 267-269). The picture is further complicated by an insistence that individual subjectivity is complex, plural, contradictory and never fully determined. As June Jordan puts it: 'every single one of us is more than whatever race we represent or embody and more than whatever gender category we fall into. We have other kinds of allegiances, other kinds of dreams' (interviewed in Parmar 1989: 61). Indeed, most black and third world feminists remain united in their aspiration to contest fixity in formulations of the political actor and to enable imaginative and physical mobility. Here the facilitating role of participation in movement politics can be stressed. Movement connections across borders are perhaps especially significant because they can enable the construction of selves whose relationship to their location is shaped by the effort to reach beyond it. For example, it could be argued that Canadian-Mexican feminist mobilisation against NAFTA forced white women in Canada to face up to the complex ethnic realities of Canadian national identity, as well as to the differences between Canadian and Mexican experiences. The emergence of more rooted, reflexive identities thus went hand in hand with the development of a more egalitarian and inclusive coalition.

Finally, the movement praxis delineated here offers an alternative to both reformist complacency and the revolutionary model of change, one that aspires to transform social and political structures through complex processes of societal self-organisation. To begin with, black and third world feminist arguments emphasise the need for movement struggles to be both multiple and ongoing, given the impossibility of perceiving the entirety of complex power relations from particular standpoints and the diverse and often unpredictable ways in which power interacts in different contexts. This is combined with a more solidaristic 
aspiration to construct connections across social and geopolitical divides. Further, three sources of power are emphasised as priorities for change in the literature I have looked at. The first is the globalising economy, which is where we find a strong convergence with feminist interventions in globalisation and global governance debates as highlighted above (e.g. Alexander and Mohanty 1997). Challenges to globalising economic forces range from developing policy and research that contextualises the oppressive features of neoliberal restructuring, to engaging in unionisation and everyday resistances, to developing community-based health and welfare projects and transnational feminist support networks (Desai 2002). The second priority for change for black and third world feminists is culture: strategies here involve an emphasis on the dual need to resist both patriarchal conservatism of localised traditions and the imposed homogenisation of hegemonic cultural forms. Cultural difference is celebrated but not uncritically; attention is paid to the need to struggle to subvert, reclaim and recreate cultural traditions and to seek connections across difference (e.g. Collins 2000: 69-121).

A third major target for black and third world feminists is the state and states-system. Some express a strong antipathy towards the state given its demonstrable potential for coercive intervention in their lives (e.g. Agarwal 1988; Alexander and Mohanty 1997). This ties in with a long-standing strand of feminist antipathy toward the state and can lead to an explicitly anti-statist politics. Yet other black and third world feminists have pursued change through state channels and through nationalist movements (e.g. Collins 2000: 216-222; Jayawaradena 1986). There are similar divergences in transnational feminist organising, between 'mainstreaming' and 'a politics of disengagement' (Stienstra 1995 and 2000; Higer 1999). In my view, these divergences point to the need for a strategic but sceptical approach to the state and inter-state organisations. This means that engagement should be recognised 
as necessary in some contexts but as likely to remain highly circumscribed and fraught with danger given the interaction of state institutions with gendered, racial and capitalist hierarchies. Those pursuing state-centric strategies should strive to involve people who are most vulnerable to the operations of state and other forms of power, and to retain connections with a range of transformatory movement struggles.

\section{Conclusion}

In sum, black and third world feminist arguments, and the ways these are played out in transnational organising, have given rise to a view of power as global in scope, multidimensional and intersecting in complex ways. This has encouraged an insistence on the need to expand democratic politics into social life and transnational relationships, but in a differentiated way, with strategy formulated in specific contexts and combined with the pursuit of connection across differences through movement politics. Such a process must be rooted in a recognition of the partiality of the perspectives that all context-specific mobilisations generate, with agreement across differences sought through open, participatory and inclusive dialogue. The development of procedures for such a dialogue is urged, alongside efforts to overcome differential access to information, resources and agenda-setting imposed by geopolitical, ethnic and class locations. This model of democratic practice is dependent upon a notion of the actor as embedded within national locations and gender, race and class identities but also as struggling for empathetic mobility through participation in movement struggles. Finally, there is a complex model of transformatory change emerging here. An emphasis on the necessary plurality of sites and sources of struggle is combined with an insistence on the need to build more general alliances between movements; economic 
and cultural sources of domination are equally prioritised; and a strategic but sceptical approach to the state is suggested.

These arguments point to the possibility of a more democratic future for feminism. Further, they are applicable to movements other than feminism and can be found in writings within and about them. I should stress that I am not resorting here to an idealised view of movements as intrinsically democratic - after all, the ideas explored in this paper have emerged from critiques of racist exclusions within feminism. Rather, I am proposing that certain strands in contemporary movements are generating democratic innovations, albeit in an as yet fairly inchoate and unsystematic manner (see e.g. essays in Brecher et al. 1993; Danaher and Burbach 2000). These innovations have been perhaps most systematically developed within the feminist movement because of the ongoing preoccupation with the marginalisation of women in mainstream approaches to democracy and because of the need for the movement to come to terms with differences between women.

Finally, it is my contention that such efforts to democratise movement politics indicate ways in which democratic theory and practice more generally could be reconfigured. The above arguments imply that strategies to extend and reconstruct democracy need to take on board issues about power, the scope of politics, agency and change if they are to overcome the significant marginalisations caused by gender hierarchies and the ways in which these are being globalised. It should be stressed that this is not intended as a wholesale replacement for state-based models of democracy or for feminist proposals to reshape citizenship and global governance. Indeed, I have pointed to convergences between the feminist global governance literature and debates about feminist movement democracy, particularly around recognition of the need for diverse strategies to confront the exclusions caused by economic 
inequality. However, the movement democracy model should be seen as a necessary supplement to both state and governance-based models, pointing to a broader and ultimately transformatory framework for social organisation which could potentially displace the state from its central position in political imaginations. Given the history of gendered marginalisations within liberal democracy and the current impact of processes of globalisation, a focus on feminist movement democracy opens up possibilities that deserve further investigation.

\section{Notes}

1. I would like to thank all those who engaged with earlier versions of this paper, presented as part of the IR/Social and Political Thought seminar series on 'The New World Order Ten Years On', University of Sussex, 29 June 2000; and at the World Congress of the International Political Studies Association, Québec City, 1-5 August 2000. Particular thanks are due to Neil Stammers and to the two anonymous reviewers for IFjP. The argument presented was originally developed as one analytical thread within a larger theoretical project (2001a). Some elements of the argument have been compressed and others elaborated and updated in line with comments received. Any remaining errors and idiosyncrasies are, of course, entirely my own.

2. David Potter's survey of the $1975-1995$ period reveals that the number of states that were either 'partial' or liberal democracies jumped from 32 to 90 per cent in Latin America and from zero to 81 per cent in the former eastern European bloc. The number of liberal democratic regimes in Asia tripled from three to nine in the same period and in Sub 
Saharan Africa 'nearly 67 per cent were either partial or liberal democracies' by 1995 (Potter et al. 1997: 8-10).

3. There are plentiful sources on these two strands of analysis in feminist international political economy. See e.g. Sassen 1996; Brodie 1994; Moghadam 1994; Vickers 1991.

4. For examples of this shift toward a fuller consideration of globalisation see e.g. Einhorn 2000; Rai 2000;Kelly et al. 2001; Yuval-Davis 1999.

5. Cox is ambiguous on timing, appearing to shift between a dual model in which movements strive to challenge national and international institutions simultaneously (see the essay on 'Globalization, multilateralism and democracy' in Cox 1996) and a twostage of model which prioritises national-level struggles (Cox 1997). More recently (1999), Cox has stressed regional differences in the impact of economic globalisation and in responding mobilisations, which points perhaps to an intermediate 'regional' stage in the consolidation of a counter-hegemonic civil society.

6. See Falk 1987 and Lipschutz 1992. Both theorists have shifted their position somewhat in recent years but their early formulations remain influential. This version of civil society theory can also be seen in Otto 1996; Wapner 1996; Turner 1998.

7. Needless to say, many black and third world women writers and activists reject the label of feminist altogether. Further, racially-based labels are essentialising and the term 'third world' is anachronistic, given the collapse of the 'second world'. Nonetheless, the term 'black and third world feminist' is used here because it is still adopted by many as a self- 
description to indicate a common location in global power structures and/or a selfconsciously constructed collective identification.

8. For a selection of classic black and third world feminist critiques of white feminism see Carby 1997; Amos and Parmar 1984; Lorde 1983; hooks 1984.

9. This example is taken primarily from Yuval-Davis 1997b:125-130. Other examples of cross-community coalition building projects, including those involving women's groups in Bosnia and in Northern Ireland, and organisations as diverse as Bat Shalom and Southall Black Sisters, are explored in Cockburn and Hunter 1999. Patricia Hill Collins' recent update of her classic text Black Feminist Thought explicitly re-frames her ideas about coalitions in terms of the concept of transversal politics (see Collins 2000: 245249).

\section{References}

Afshar, Haleh and Stephanie Barrientos (eds). 1999. Women, Globalization and Fragmentation in the Developing World. Basingstoke: Macmillan.

Agarwal, Bina (ed.). 1988. Structures of Patriarchy: The State the Community and the Household. London: Zed Books.

Alexander, M. Jacqui and Chandra Talpade Mohanty. 1997. 'Genealogies, Legacies, Movements' in M. Jacqui Alexander and Chandra Talpade Mohanty (eds) Feminist Genealogies, Colonial Legacies, Democratic Futures, pp. xiii-xlii. London: Routledge. 
Alvarez, Sonia E. 1999. 'Advocating Feminism: The Latin American Feminist NGO Boom', International Feminist Journal of Politics 1 (2): 181-209.

Amin, Samir, Giovanni Arrighi, Andre Gunder Frank and Immanuel Wallerstein (eds). 1990.

Transforming the Revolution: Social Movements and the World System. New York:

Monthly Review Press.

Amos, Valerie and Pratibha Parmar. 1984. 'Challenging Imperial Feminism', Feminist Review 17: 3-19.

Arrighi, Giovanni, Terence K. Hopkins and Immanuel Wallerstein. 1989. Antisystemic Movements. London: Verso.

Basu, Amrita, Inderpal Grewal, Caren Kaplan, Liisa Malkki (eds). 2001. 'Globalization and Gender', Signs: Journal of Women in Culture and Society, Special Issue 26 (4): $943-$ 1314.

Beechey, Veronica. 1979. 'On Patriarchy', Feminist Review 3: 67-82.

Benhabib, Seyla. 1996. 'Toward a Deliberative Model of Democratic Legitimacy' in Seyla Benhabib (ed.) Democracy and Difference: Contesting the Boundaries of the Political, pp. 67-94. Princeton NJ: Princeton University Press.

Benhabib, Seyla and Drucilla Cornell. 1987. 'Introduction: Beyond the Politics of Gender' in Seyla Benhabib and Drucilla Cornell (eds) Feminism as Critique: Essays on the Politics of Gender in Late-Capitalist Societies, pp. 1-15. Cambridge: Polity Press.

Brecher, Jeremy, John Brown Childs and Jill Cutler (eds). 1993. Global Visions: Beyond the New World Order. Boston: South End Press.

Brodie, Janine. 1994. 'Shifting the Boundaries: Gender and the Politics of Restructuring', in Isabella Bakker (ed.) The Strategic Silence: Gender and Economic Policy, pp. 46-60. London: Zed Books. 
Brown, Wendy. 1995. States of Injury: Power and Freedom in Late Modernity. Princeton, NJ: Princeton University Press.

Bunch, Charlotte. 1987. Passionate Politics: Feminist Theory in Action. New York: St. Martin's Press.

Carby, Hazel. 1997. 'White Woman Listen! Black Feminism and the Boundaries of Sisterhood' in Heidi Safia Mirza (ed.) Black British Feminism: A Reader. London: Routledge.

Cockburn, Cynthia and Lynette Hunter (eds). 1999.'Transversal Politics', Soundings Special Issue 12: 88-162.

Cohen, Jean L. and Andrew Arato. 1992. Civil Society and Political Theory. Cambridge, MA: MIT Press.

Colas, Alejandro. 2002. International Civil Society: Social Movements in World Politics. Oxford: Polity.

Collins, Patricia Hill. 2000. Black Feminist Thought: Knowledge, Consciousness and the Politics of Empowerment. $2^{\text {nd }}$ Edition. London: Routledge.

Commission on Global Governance. 1995. Our Global Neighbourhood. Oxford: Oxford University Press.

Cox, Robert. 1999. 'Civil Society at the Turn of the Millennium: Prospects for an Alternative World Order', Review of International Studies 25 (1): 3-28. 1997. Democracy in Hard Times: Economic Globalization and the Limits to Democracy' in Anthony McGrew (ed.) The Transformation of Democracy? Globalization and Territorial Democracy, pp. 49-72. Cambridge: Polity Press. . 1996. Approaches to World Order, with Timothy J. Sinclair. Cambridge:

Cambridge University Press. 
Crenshaw, Kimberle. 1998. 'Demarginalizing the Intersections of Race and Sex: a Black Feminist Critique of Anti-Discrimination Doctrine, Feminist Theory and Anti-Racist Politics' in Anne Phillips (ed.) Feminism and Politics, pp. 314-343. Oxford: Oxford University Press.

Danaher, Kevin and Roger Burbach 2000. Globalize This! The Battle Against the World Trade Organization and Corporate Rule. Monroe, Maine: Common Courage Press. Desai, Manisha. 2002. ‘Transnational Solidarity: Women’s Agency, Structural Adjustment and Globalization' in Nancy Naples and Manisha Desai (eds) Women's Activism and Globalization: Linking Local Struggles and Transnational Politics, pp. 15-33. London: Routledge.

Dickenson, Donna. 1997. 'Counting Women In: Globalization, Democratization and the Women's Movement' in Anthony McGrew (ed.) The Transformation of Democracy? Globalization and Territorial Democracy, pp. 97-120. Cambridge: Polity Press.

Dietz, Mary. 1992. 'Context is All: Feminism and Theories of Citizenship' in Chantal Mouffe (ed.) Dimensions of Radical Democracy: Pluralism, Citizenship, Community, pp. 63-85. London, Verso.

Einhorn, Barbara 2000. 'Gender and Citizenship in the Context of Democratisation and Economic Reform in East Central Europe' in Shirin M. Rai (ed.) International Perspectives on Gender and Democratisation, pp. 103-124. Basingstoke: Macmillan. Einhorn, Barbara. 1993. Cinderella Goes to Market: Citizenship, Gender and Women's Movements in East Central Europe. London: Verso.

Elshtain, Jean Bethke. 1990. Power Trips and Other Journeys: Essays in Feminism as Civic Discourse. Madison: University of Wisconsin Press. 1981. Public Man, Private Woman: Women in Social and Political Thought. Oxford: Martin Robertson. 
Eschle, Catherine. 2001a. Global Democracy, Social Movements and Feminism. Boulder, CO: Westview Press. . 2001b. 'Globalising Civil Society? Social Movements and the Challenge of

Global Politics from Below' in Pierre Hamel, Henri Lustiger-Thaler, Jan Nederveen Pieterse and Sasha Roseneil (eds) Globalization and Social Movements, pp. 61-85. Basingstoke: Palgrave.

Eschle, Catherine and Neil Stammers.2001. 'Taking Part: Social Movements, INGOs and Global Change', paper presented at the 4th Annual Conference of the European Sociological Association, Helsinki, Finland, September.

Falk, Richard A. 1987. 'The Global Promise of Social Movements: Explorations at the Edge of Time', Alternatives XII: 173-196.

Freeman, Jo. 1984. 'The Tyranny of Structurelessness', in Untying the Knot: Feminism, Anarchism and Organisation, pp. 5-16. London, Dark Star/Rebel Press.

Gabriel, Christina and Laura Macdonald. 1994. 'NAFTA, Women and Organising in Canada and Mexico: Forging a Feminist Internationality', Millennium: Journal of International Studies 23 (3): 535-556.

Giddens, Anthony. 1994. Beyond Left and Right: The Future of Radical Politics. Cambridge: Polity Press.

Hanochi, Seiko .2001. 'Japan and the Global Sex Industry’ in Rita Mae Kelly, Jane H. Bayes, Mary E. Hawkesworth and Brigitte Young (eds)Gender, Globalization and Democratization, pp. 137-146. Lanham, Maryland: Rowman and Littlefield.

Hawkesworth, Mary E. 2001. 'Democratization: Reflections on Gendered Dislocations in the Public Sphere' in Rita Mae Kelly, Jane H. Bayes, Mary E. Hawkesworth and Brigitte Young (eds) Gender, Globalization and Democratization, pp. 223-236. Lanham, Maryland: Rowman and Littlefield. 
Held, David. 1998. 'Democracy and Globalization' in Daniele Archibugi, David Held and Martin Köhler (eds) Re-Imagining Political Community, pp. 11-27. Cambridge: Polity Press. 1995. Democracy and the Global Order. Cambridge: Polity Press. 1991. 'Democracy, the Nation-state and the Global System', Economy and Society 20 (2): 138-172.

Held, Virginia. 1993. Feminist Morality: Transforming Culture, Society and Politics. Chicago: Chicago University Press.

Higer, Amy J. 1999. 'International Women's Activism and the 1994 Cairo Population Conference' in Mary K. Meyer and Elisabeth Prügl (eds) Gender Politics in Global Governance, pp. 122-141. London: Rowman and Littlefield.

hooks, bell. 1984. Feminist Theory: From Margin to Center. Boston, MA: South End Press. Huntington, Samuel P. 1991. The Third Wave: Democratization in the Late Twentieth Century. London: University of Oklahoma Press.

Inter-Parliamentary Union. 2001. 'Women in National Parliaments', http://wwww.ipu.org/wmn-e/classif.htm (visited 9 May 2002).

Jaquette, Jane S. 2001. 'Women and Democracy: Regional Differences and Contrasting Views', Journal of Democracy 12 (3): 111-125. 1997. 'Women in Power: from Tokenism to Critical Mass', Foreign Policy 108: 23-37.

Jaquette, Jane S. and Sharon L. Wolchik. 1998. 'Women and Democratization in Latin America and Eastern Europe: A Comparative Introduction' in Jane S. Jaquette and Sharon Wolchik (eds) Women and Democracy: Latin America and Central and Eastern Europe, pp. 1-28. Baltimore and London: John Hopkins University Press. 
Jayawaradena, Kumari. 1986. Feminism and Nationalism in the Third World. London: Zed Books.

Jones, Kathleen B. 1990. 'Citizenship in a woman friendly polity', Signs: Journal of Women in Culture and Society 15 (4): 781-812.

Kelly, Rita Mae, Jane H. Bayes, Mary E. Hawkesworth and Brigitte Young (eds) .2001. Gender, Globalization and Democratization. Lanham, Maryland: Rowman and Littlefield

King, Deborah K. 1988. 'Multiple Jeopardy, Multiple Consciousness: The Context of a Black Feminist Ideology', Signs: Journal of Women in Culture and Society 14 (1): 42-72. Klimenkova, Tatania. 1994. 'What Does our New Democracy Offer Society?' in Anastasia Posadskaya (ed.) Women in Russia: A New Era in Russian Feminism, pp. 17-23. London: Verso.

Levine, Cathy. 1984. 'The Tyranny of Tyranny' in Untying the Knot: Feminism, Anarchism and Organisation, pp. 17-23. London: Dark Star/Rebel Press.

Lipschutz, Ronnie D. 1992. 'Reconstructing World Politics: The Emergence of Global Civil Society', Millennium: Journal of International Studies 21 (3): 389-420.

Lister, Ruth. 1997. Citizenship: Feminist Perspectives. Basingstoke: Macmillan.

Lorde, Audre. 1983. 'An Open Letter to Mary Daly’ in Cherríe Moraga and Gloria Anzaldúa (eds) This Bridge Called my Back: Writings by Radical Women of Color. $2^{\text {nd }}$ Edition, pp. 94-101. New York, Kitchen Table-Women of Color Press.

Luckham, Robin and Gordon White (eds). 1996. Democratization in the South: The Jagged Wave. Manchester, Manchester University Press.

Marchand, Marianne H. and Anne Sisson Runyan (eds). 2000. Gender and Global Restructuring: Sightings, Sites and Resistances. London: Routledge. 
Meyer, Mary K. and Elisabeth Prügl (eds) Gender Politics and Global Governance. Lanham, Maryland: Rowman and Littlefield.

Moghadam, Valentine M. 1995. 'Transnational Feminist Networks: Collective Action in an Era of Globalization', International Sociology 15 (1): 57-85.

Mohanty, Chandra Talpade. 1998. 'Feminist Encounters: Locating the Politics of Experience' in Anne Phillips (ed.) Feminism and Politics, pp. 254-272. Oxford: Oxford University Press.

Morgan, Robin (ed.). 1985. Sisterhood is Global: The International Women's Movement Anthology. Harmondsworth: Penguin Books.

Mouffe, Chantal. 1993. The Return of the Political. London: Verso.

O’Brien, Robert, Anne Marie Goetz, Jan Aart Scholte and Marc Williams. 2000. Contesting Global Governance: Multilateral Economic Institutions and Global Social Movements. Cambridge: Cambridge University Press.

Otto, Dianne. 1996. 'Nongovernmental Organizations and the United Nations System: the Emerging Role of International Civil Society', Human Rights Quarterly 18: 107-141.

Pankhurst, Donna. 2002. 'Women and Politics in Africa: the case of Uganda', Parliamentary Affairs 55: 119-128.

Parmar, Pratibha. 1989. 'Other Kinds of Dreams’, Feminist Review 31: 55-65.

Passerini, Luisa. 1994. 'The Interpretation of Democracy in the Italian Women's Movement of the 1970s and 1980s', Women's Studies International Forum 17 (2-3): 235-239.

Pateman, Carole. 1989. The Disorder of Women: Democracy, Feminism and Political Theory. Cambridge: Polity Press.

Peterson, V. Spike .2002. 'Rewriting (Global) Political Economy as Reproductive, Productive and Virtual (Foucauldian) Economies', International Feminist Journal of Politics 4 (1): 1-30. 
Phillips, Anne. 1995. The Politics of Presence. Oxford: Clarendon Press. . 1991. Engendering Democracy. Cambridge: Polity Press.

Posadskaya, Anastasia (ed.). 1994. Women in Russia: A New Era in Russian Feminism. London Verso.

Potter, David, David Goldblatt, Margaret Kiloh and Paul Lewis (eds). 1997.

Democratization. Cambridge: Polity Press in association with the Open University.

Rai, Shirin M. 2000. 'International Perspectives on Gender and Democratisation' in Shirin

M. Rai (ed.) International Perspectives on Gender and Democratisation, pp. 1-16.

Basingstoke: Macmillan.

Reagon, Bernice Johnson. 1983. 'Coalition Politics: Turning the Century' in Barbara Smith (ed.) Home Girls: A Black Feminist Anthology, pp. 356-368. New York: Kitchen Table -Women of Color Press.

Rowbotham, Sheila. 1986. 'Feminism and Democracy' in David Held and Christopher Pollit (eds) New Forms of Democracy, pp. 78-104. London: SAGE in association with the Open University.

Ruddick, Sara. 1990. Maternal Thinking: Towards a Politics of Peace. London: Women's Press.

Runyan, Anne Sisson. 1999. 'Women in the Neoliberal "Frame"' in Mary K. Meyer and Elisabeth Prügl (eds) Gender Politics in Global Governance, pp. 210-220. Lanham, Maryland: Rowman and Littlefield.

Sandoval, Chéla. 1995. 'Feminist Forms of Agency and Oppositional Consciousness: U.S. Third World Feminist Criticism' in Judith Kegan Gardiner (ed.) Provoking Agents: Gender and Agency in Theory and Practice. Urbana and Chicago: University of Illinois Press. 
Sassen, Saskia. 1996. 'Toward a Feminist Analytics of the Global Economy', Indiana Journal of Global Legal Studies 4 (1): 7-41.

Squires, Judith and Mark Wickham-Jones. 2001. Women in Parliament: A Comparative Analysis. Manchester: Equal Opportunities Commission.

Stienstra, Deborah.2000. 'Dancing Resistance from Rio to Beijing: Transnational Women's Organising and United Nation Conferences 1992-1996' in Marianne H. Marchand and Anne Sisson Runyan (eds) Gender and Global Restructuring: Sightings, Sites and Resistances, pp. 209-224. London: Routledge. . 1999. 'Of Roots, Leaves, and Trees: Gender, Social Movements, and Global

Governance' in Mary K. Meyer and Elisabeth Prügl (eds) Gender Politics in Global Governance, pp. 260-272. London: Rowman and Littlefield. . 1995. 'Organising for Change: International Women's Movements and

World Politics in Francine D'Amico and Peter R Beckman (eds) Women in World Politics: An Introduction, pp. 143-154. Westport, CT: Bergin and Garvey.

Tinker, Irene and Jane Jaquette. 1987. 'UN Decade for Women: its Impact and Legacy’, World Development 15 (3): 419-427.

Turner, Scott. 1998. 'Global Civil Society, Anarchy and Governance: Assessing an Emerging Paradigm', Journal of Peace Research 35 (1): 25-42.

Vickers, Jeanne. 1991. Women and the World Economic Crisis. London: Zed Books.

Walby, Sylvia. 1990. Theorizing Patriarchy. Oxford, Basil Blackwell.

Wapner, Paul K. 1996. Environmental Activism and World Civic Politics. Albany NY: State University of New York Press.

Ward, Anna, Jeanne Gregory and Nira Yuval-Davis (eds). 1992. Women and Citizenship in Europe - Borders, Rights and Duties: Women's Differing Identities in a Europe of Contested Boundaries. Stoke On Trent: Trentham Books. 
Waterman, Peter. 1998. Globalization, Social Movements and the New Internationalisms. London: Mansell.

Watson, Peggy. 1993. 'The Rise of Masculinism in Eastern Europe', New Left Review 198: $71-82$.

Waylen, Georgina . 2000. 'Gender and Democratic Politics: A Comparative Analysis of Consolidation in Argentina and Chile', Journal of Latin American Studies 32: 765793.

Whitehead, Laurence. 1996. 'Concerning international support for democracy in the South' in Robin Luckham and Gordon White (eds) Democratization in the South: The Jagged Wave. Manchester, Manchester University Press.

Young, Iris Marion. 2000. Inclusion and Democracy. Oxford: Oxford University Press. . 1996. 'Communication and the Other: Beyond Deliberative Democracy' in Seyla Benhabib (ed.) Democracy and Difference: Contesting the Boundaries of the Political, pp. 120-135. Princeton, NJ: Princeton University Press. 1990. Justice and the Politics of Difference. Princeton, NJ: Princeton

University Press.

Yuval-Davis, Nira. 1999. 'Latin American Feminism in the 1990s: A Conversation with Gina Vargas', International Feminist Journal of Politics 1 ( 2): 300-310. . 1997a. 'Women, Citizenship and Difference', Feminist Review 57: 4-27. 1997b. Gender and Nation. London: SAGE. 
